\title{
$\mathrm{PC}$ 큰 보-PC 작은 보 접합부의 전단성능 평가
}

\section{Evaluation of Shear Capacity on PC Girder-PC Beam Joint}

\author{
문 정 호 ${ }^{1)}$ \\ 오 영 훈 $^{2)}$ \\ 임 재 형 3 ** \\ Moon, Jeong Ho \\ Oh, Young Hun \\ Lim, Jae Hyung
}

\begin{abstract}
The object of this study is to evaluate the structural shear capacity of the PC girder-PC beam joint. The dapped end of PC beam and the ledger of PC girder are usually designed to design load. If the end of PC beam can be designed with continuous end, the dapped end of PC beam and the ledger of PC girder do not need to resist to all loads except dead load and construction load. The experimental program was carried out with 7 specimens containing the variable factors as the anchored method of the hanger bar, design load, be or not exist of ledger bars. As a result, the continuity of the dapped end and the ledger were ensured their safety although the design load was only the dead load and the construction load. The shear critical section was expanded toward the effective depth $\mathrm{d}$, the distance from the supported position of the beam. If the ledger is designed according to PCI Design Handbook ${ }^{4)}$, the structural system of the ledger is as to the cantilever slab system. But the ledger of this study is as to the 3 side fixed slab system. Therefore the design of the ledger by PCI Design Handbook will lead to highly conservative results.
\end{abstract}

Keywords : PC girder-PC beam joint, Dapped end, Ledger, Shear capacity

\section{1. 서 론}

1980년대 국내 건물에 적용된 PC 공법은 해외에서 도 입되거나 국내에서 개발된 벽식구조 형식인 Full PC 공 법으로써 주로 아파트공사에 적용되었다. 그러나 1990년 대 및 2000년대에는 국내 건설사들이 아파트 이외의 건 물에 적용할 수 있는 다양한 PC 공법을 개발하였으며, 그 중에서도 하프 $\mathrm{PC}$ 형 골조식 공법이 실제로 많이 적용되 고 있다.

현재의 하프 $\mathrm{PC}$ 형 골조식 공법에서의 작은 보는 단순 지지 형식의 보로 설계된다. 즉 $\mathrm{PC}$ 큰 보(girder)에 $\mathrm{PC}$ 작은 보(beam)가 접합될 때, Fig. 1에서와 같이 작은 보 가 큰 보의 레져(ledger)에 얹어지고 작은 보의 상부근은 최소철근만 배근되는 형식이다. 이러한 접합부에서 큰 보 의 레져는 작은 보에 작용하는 사용하중에 안전하도록 설 계되어야 하며, 작은 보의 댑단부(dapped end) ${ }^{5), 6), 7)}$ 도 사용하중에 안전하도록 설계되어야 한다. 그러나 작은 보 의 단부가 연속단으로 설계된다면, 큰 보의 레져나 작은

\footnotetext{
1) 정회원, 한남대학교 건축공학과 교수

2) 정회원, 건양대학교 건축공학과 교수

3) 정회원, 우송정보대학 리모델링건축과 교수
}

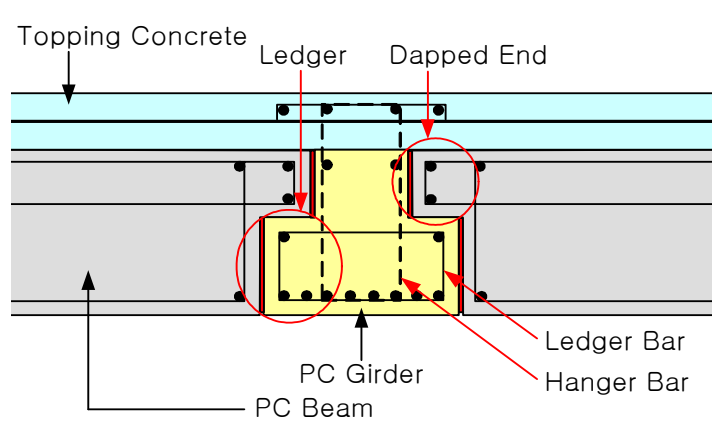

Fig. 1 PC Girder-PC Beam Joint Detail

보의 댑단부는 고정하중 및 시공하중에만 안전하도록 설 계하면 된다. 이상과 같이 작은 보를 연속보로 설계하면 단순보로 설계할 때 보다 댑단부의 보강철근량을 감소시 킬 수 있으며, 작은 보의 부재크기와 인장철근량도 감소 시킬 수 있는 효과를 기대할 수 있다.

또한 Fig. 1에 나타낸 바와 같이 PC 큰 보의 전단보강 용 행거철근이 덧침 콘크리트에 정착되도록 제작되는데, 이때 행거철근을 가로지르는 보의 상부근이 배근되지 못

\footnotetext{
* Corresponding author : phd-lim@daum.net 010-3686-3129

- 본 논문에 대한 토의를 2011년 12월 31일까지 학회로 보내주시면 2012년 1 월호에 토론결과를 게재하겠습니다.
} 
하는 경우도 발생하기 때문에 행거철근이 덧침 콘크리트 에 정착되지 못하고 $\mathrm{PC}$ 큰 보 내에 정착되도록 하는 경우 도 있다. 이러한 경우는 전단보강용 행거철근의 길이가 짧아지기 때문에 이에 대한 구조성능 평가도 필요하다.

따라서 본 연구에서는 작은 보의 댑단부와 큰 보의 레 져에 대한 전단성능을 평가하기 위한 전단 구조성능 실험 을 실시하여 작은 보의 연속단 구조설계의 가능성을 검토 하고자 한다.

\section{2. 설계방법 및 기존연구 고찰}

하프 PC형 골조구조에서 작은 보는 연속보로 설계되지 않고 단순지지 형식의 보로 설계되는 것이 일반적이다. 그러나 작은 보를 연속보로 설계할 수 있다면 큰 보-작 은 보 접합부에 대한 설계 시 경제적인 설계가 가능하다. 이와 같은 장점 때문에 최근에 일본 및 국내에서는 작은 보를 연속보로 설계하고 있으며, 또한 실제 건물에 적용 된 사례가 있다. 그러나 작은 보의 연속단 접합부 및 큰 보-작은 보 접합부에 대한 구조성능을 확인하는 연구가 많지 않으며, 특히 이러한 접합부에서 구조상세는 단순지 지 상태에 대하여 개발된 설계기준을 적용하고 있는 상황 이다. 따라서 본 장에서는 하프 $\mathrm{PC}$ 합성 골조구조의 작은 보의 연속단 및 큰 보-작은 보 접합부의 설계와 구조성 능 평가에 관련된 설계기준 및 기존 연구에 대하여 정리. 분석하고, 연구의 진행방향을 결정하였다.

\section{1 댑단부(dapped end) 및 레져(ledger)의 설계}

프리캐스트 또는 프리스트레스트 콘크리트 구조의 바 닥판 구조시스템은 층고를 줄이기 위한 목적으로 보 단부 의 지지부분 높이를 작게 한 댑(dap)을 사용하는 경우가 많다. 댑단부를 갖는 보는 수직 또는 경사균열이 발생할 수 있으므로 이러한 균열면에서 파괴가 발생하지 않도록 설계하여야 하는데, 이들은 사용하중 $(\mathrm{DL}+\mathrm{LL})$ 에 안전하 여야 한다. 그러나 합성 $\mathrm{PC}$ 구조의 작은 보는 시공할 때 고정하중과 덧침 콘크리트 타설을 위한 시공하중에 안전 하여야 하지만, 덧침 콘크리트가 양생된 이후의 완성단계 에서는 사용하중 $(\mathrm{DL}+\mathrm{LL})$ 에 저항하여야 한다. 즉 완성단 계에서는 연속단 접합부의 인장측에 배근된 부모멘트 철 근과 압축부 콘크리트가 활하중에 저항하여야 한다.

따라서 합성 $\mathrm{PC}$ 작은 보의 연속단 접합부는 시공단계
에서 큰 보의 레져(ledger)로 힘의 전달이 이루어지고, 완성단계에서 추가로 작용하는 활하중은 덧침 콘크리트 슬래브를 통하여 직접 큰 보에 힘의 전달이 이루어지는 메카니즘을 형성한다. 그러므로 작은 보의 단부에 형성되 는 댑단부의 전단설계는 시공단계에 따라 변화하는 힘의 전달메카니즘을 반영하여야 한다. 즉 합성 $\mathrm{PC}$ 작은 보의 연속단 접합부에서 댑단부의 전단설계는 단순지지 상태 를 대상으로 개발된 PCI 핸드북)을 적용할 경우, 콘크리 트구조설계기준 ${ }^{1}$ 의 하중계수를 사용하여 고정하중과 활 하중의 하중조합에 의한 계수전단력을 적용하게 되지만, 시공단계에 따라 힘의 전달메카니즘이 변화한다는 것을 고려한다면 시공단계에서는 고정하중의 계수전단력을 적 용하여 댑단부의 전단설계를 수행하는 것이 타당할 것이 다. 그러므로 댑단부를 갖는 보가 시공과정에서는 단순지 지 상태이지만, 덧침 콘크리트를 타설한 이후에는 연속단 이 될 수 있도록 부모멘트 저항능력을 갖는 댑단부의 보 강근을 산정할 수 있다.

그리고 PCI 핸드북에서는 레져를 설계할 때에도 더블 티를 지지하는 캔틸레버형 레져(ledger)의 설계법을 제 시하고 있지만, 본 공법에서 큰 보에 형성된 레져는 3 변 고정슬래브와 같은 형태이므로 $\mathrm{PCI}$ 핸드북에서 제시하고 있는 레져의 설계법으로 설계되는 것은 불합리하다. 따라 서 큰 보에 형성된 레져는 시공단계에서 고정하중의 계수 전단력를 적용하고 3 변 고정슬래브의 형태로 설계되어야 할 것이다.

\subsection{PC 연속단 접합부에 대한 연구결과 ${ }^{2,3)}$}

$\mathrm{PC}$ 연속단 접합부에 대한 기존 연구는 Fig. 2와 Fig. 3 에 나타난 기둥-큰 보 연속단 접합부와 Multi-ribbed

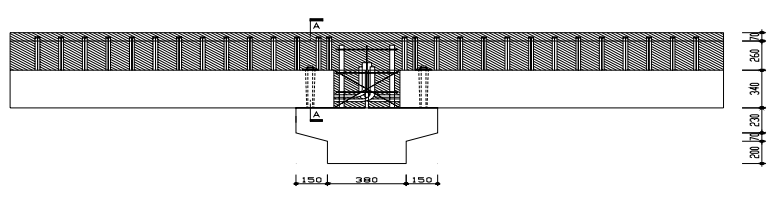

Fig. 2 Continuous joint of Column-Girder

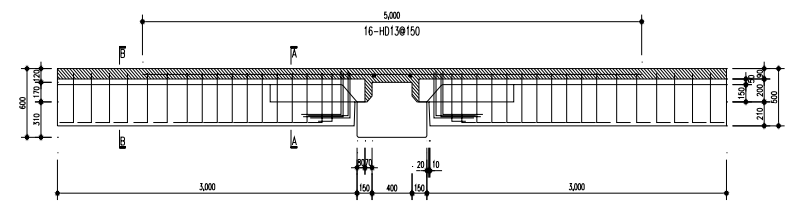

Fig. 3 Continuous joint of MRS 
moment Resisting Slab(이하 MRS로 함) 연속단 접합 부를 대상으로 연속단 접합부의 휨성능을 평가하였다. 특 히 MRS 연속단 접합부는 시공과정에 따른 하중전달 메 카니즘을 고려하여 댑단부의 전단설계를 수행하였다.

시공단계를 고려하기 위하여 댑단부에 고정하중 및 고 정하중+활하중 등 하중을 다르게 작용하여 설계한 실험 체를 대상으로 이론적 검증을 수행하고 그 결과를 반영한 실험체를 대상으로 실험을 수행하였다. 그 결과 댑단부의 전단설계를 위한 설계하중으로서 고정하중을 적용한 실 험체도 경간 길이의 $1 \%$ 에 해당하는 변형상태까지 연성적 인 휨거동을 보여주었으며, MRS의 댑단부를 경사진 형 상으로 설계한 실험체는 전통적인 댑단부 형상을 갖는 실 험체와 비교할 때, 내력과 변형능력 면에서 큰 차이가 없 는 것으로 나타났다. 따라서 Table 1에 나타낸 바와 같이 $\mathrm{MRS}$ 의 댑단부 설계는 시공상태의 하중 $(\mathrm{CL})$ 을 대상으로 수행하며, 완성단계에서는 활하중을 포함한 사용하중 (FL)이 작용하는 상태에 대하여 연속단 설계를 수행할 수 있음을 알 수 있었다.

Table 1 Applied load with construction process of MRS continuous joint

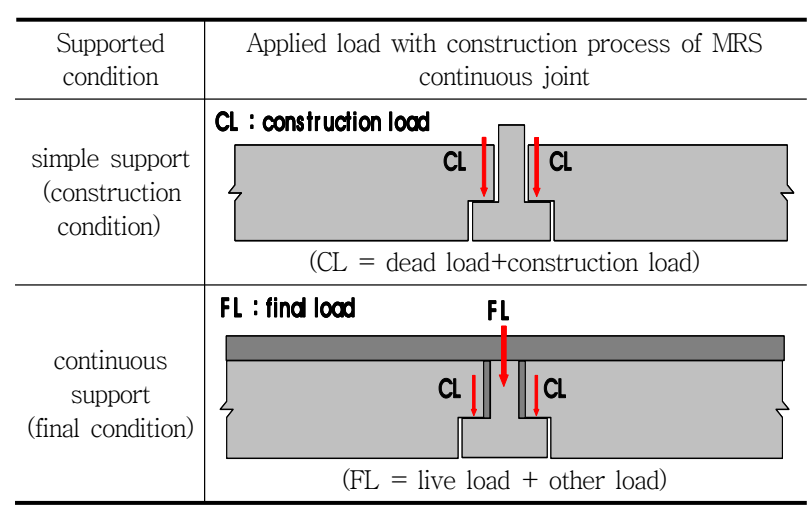

\section{3. 실 험}

\section{1 실험체 계획 및 설계}

본 실험에 적용된 PC 공법은 슬래브 밑면까지 PC 보이 고, 그 위에 하프 $\mathrm{PC}$ 슬래브를 설치한 후 설계바닥면까지 덧침 콘크리트를 타설하여 일체화하는 구조이다.

실험체 계획은 실제 시공될 아파트 지하주차장 건물을 대상으로 큰 보와 작은 보가 만나는 접합부로 하였다. 큰 보-작은 보 접합부는 건물전체를 구성하는 모듈 중에서 대표성을 나타낼 수 있는 모듈 부분으로 하였다. 실험체 의 크기는 실제 크기로 하였고, 큰 보-작은 보 접합부는 큰 보의 레져부분에 작은 보의 댑단부가 걸쳐지면서 덧침 콘크리트에 의하여 작은 보와 큰 보가 일체로 구성되는 데, 이 때 댑 - 레져 · PC 보 부분에서의 전단성능이 확보 되는지를 평가하는 것이 본 연구에서의 실험이다.

실험은 Table 2에 나타낸 바와 같은 변수로 지하주차 장을 $\mathrm{PC}$ 공법으로 적용할 경우에 대하여 작은 보를 연속 보로 설계한 후, 전단성능을 평가하는 실험체 7 개를 제작 하여 수행되었다. 또한 실험체 상세를 Fig. 4 에 나타내었 다. 실험변수에 대한 설명은 다음과 같다.

레져부분에서의 전단력에 대한 전단 성능과 댑단부의 전단 성능을 평가하기 위하여 단순보로 설계할 경우의 설 계하중 $(\mathrm{DL}+\mathrm{LL})$ 과 연속보로 설계할 경우에 대한 설계하 중 $(\mathrm{DL}+\mathrm{CL})$ 을 변수로 실험체를 설계하였으며, 또한 레져 철근의 역할을 확인하기 위하여 레져철근의 보강유무를 변수로 하였다. 그리고 레져부분에 배근되는 행거철근의 정착방법에 따른 구조성능을 확인하기 위하여 행거철근 의 정착방법을 변수로 실험체를 설계하였다. 모든 실험체 의 휨철근은 전단파괴가 발생하도록 충분히 보강하였고, $\mathrm{BS}-\mathrm{S} 1,2$ 및 $\mathrm{BS}-\mathrm{P0}, 1,2$ 실험체는 $\mathrm{PC}$ 작은 보가 전단에

Table 2 Design load of specimens

\begin{tabular}{|c|c|c|c|c|c|}
\hline Specimen & Flexural bars & Anchored place of hanger bar & Beam shear & Design load of dapped end & Design load of ledger \\
\hline $\mathrm{BS}-\mathrm{S} 1$ & \multirow{7}{*}{ Over reinforced } & \multirow{2}{*}{ Slab } & \multirow{5}{*}{ Over reinforced } & \multirow{5}{*}{ Over reinforced } & $\mathrm{DL}+\mathrm{CL}$ \\
\hline $\mathrm{BS}-\mathrm{S} 2$ & & & & & $\mathrm{DL}+\mathrm{LL}$ \\
\hline BS-P0 & & \multirow{5}{*}{$\mathrm{PC}$ beam } & & & not ledger bar \\
\hline $\mathrm{BS}-\mathrm{P} 1$ & & & & & $\mathrm{DL}+\mathrm{CL}$ \\
\hline $\mathrm{BS}-\mathrm{P} 2$ & & & & & $\mathrm{DL}+\mathrm{LL}$ \\
\hline $\mathrm{BS}-\mathrm{P} 3$ & & & \multirow{2}{*}{$\mathrm{DL}+\mathrm{LL}$} & $\mathrm{DL}+\mathrm{CL}$ & $\mathrm{DL}+\mathrm{CL}$ \\
\hline $\mathrm{BS}-\mathrm{P} 4$ & & & & $\mathrm{DL}+\mathrm{LL}$ & $\mathrm{DL}+\mathrm{LL}$ \\
\hline $\begin{aligned} \text { Note }: & \text { DL }+ \\
& \text { DL }+\end{aligned}$ & $\begin{array}{l}\text { ad Load + Live } \\
\text { ad Load + Cons }\end{array}$ & n Load & & & \\
\hline
\end{tabular}




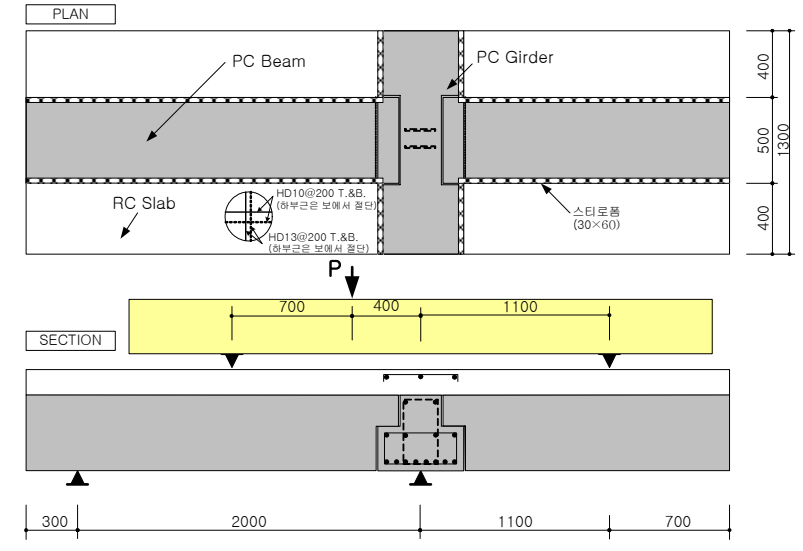

Fig. 4(a) Size of BS series specimen
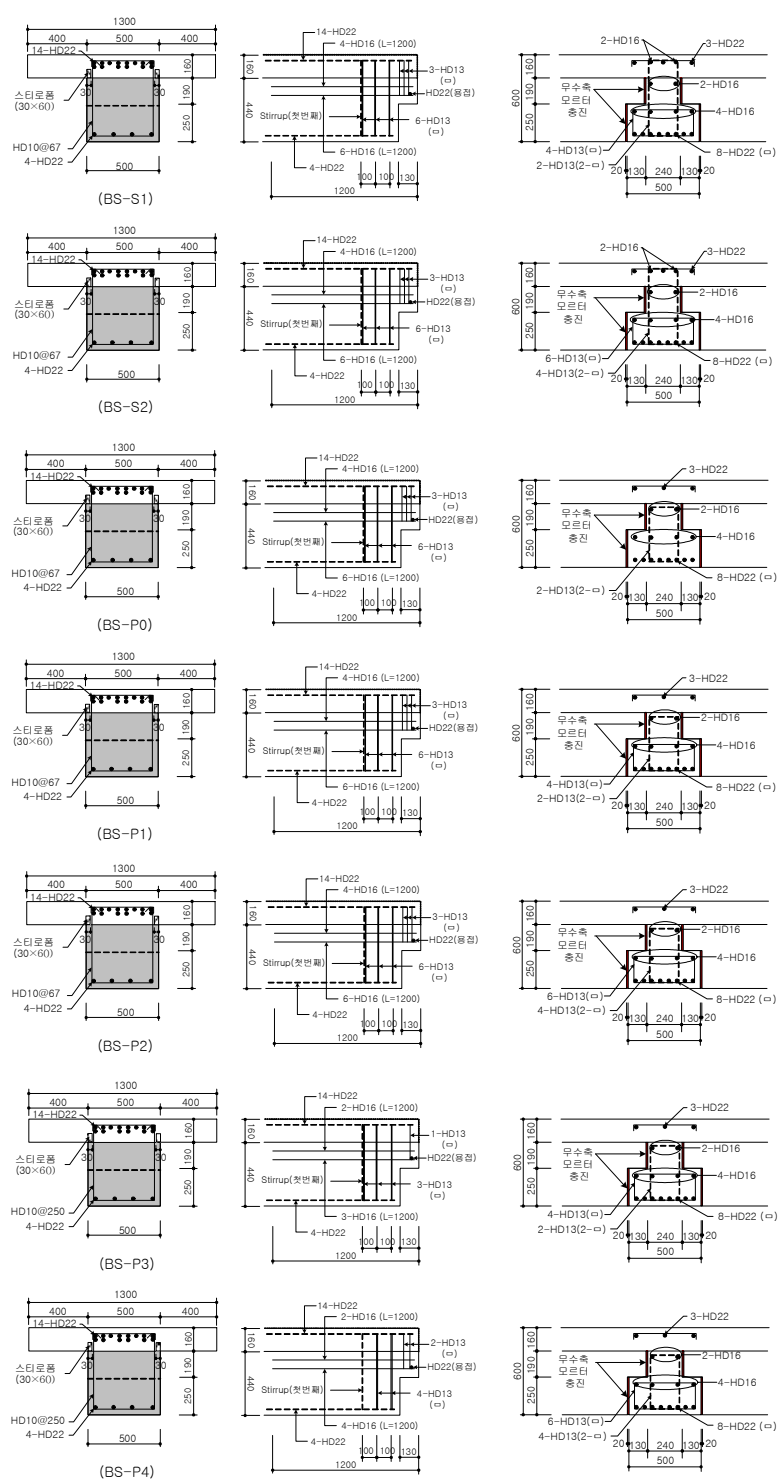

Fig. 4(b) Beam detail of BS series specimen

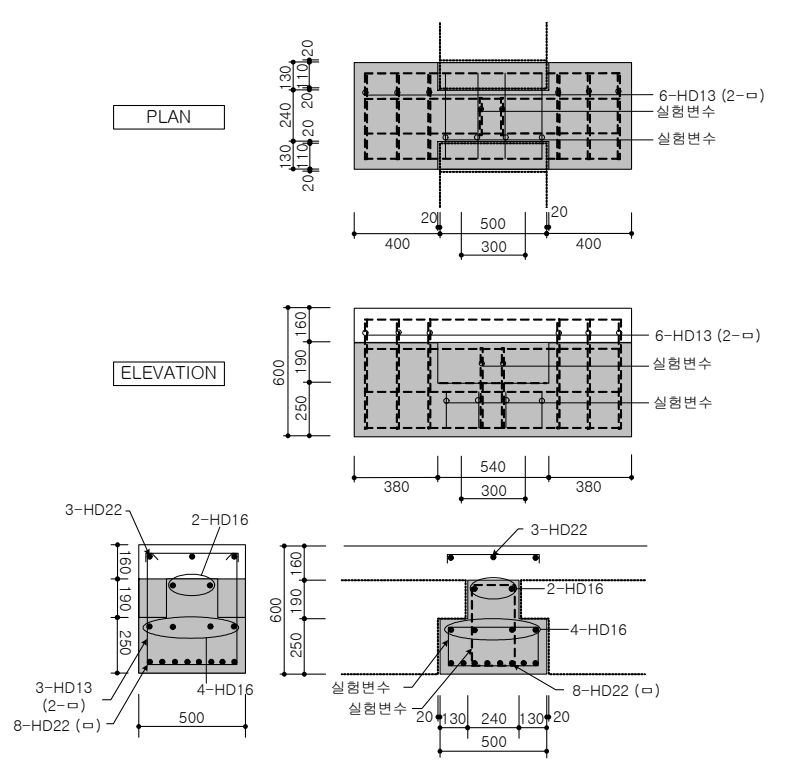

Fig. 4(c) Girder detail

안전하도록 충분히 보강(임계단면 및 댑단부의 전단설계) 하였다.

실험에 사용되는 변수는 현장실무자들과의 협의에 의 하여 가장 시급하게 구조성능을 평가하여야 할 내용을 고 려하여 결정되었다. 모든 실험체는 $\mathrm{PC}$ 콘크리트와 현장 타설 콘크리트가 일체로 완전 합성이 이루어질 수 있도록 콘크리트구조설계기준 ${ }^{1)}$ 에 따라 마찰전단에 안전하도록 설계되었다.

\section{2 측정방법}

실험을 진행하면서 실험체의 구조적 거동, 즉 변위를 파악하기 위하여 LVDT(Linear Variable Displacement Transducer)를 설치하였는데, 본 실험은 전단력이 댑단 부에서 시작하여 레져를 통하여 큰 보로 전달하는 실험이 므로 단조하중 가력개념에 따라 하중이 작용하는 점과 작 은 보와 큰 보가 만나는 곳에서 작은 보와 큰 보의 변위를 측정하였다. 하중 가력은 변위제어방식에 의한 단조가력 방식을 채택하였다. 실험은 실험체가 완전 파괴되거나, 최대하중에 도달된 이후 하중이 감소하여 최대내력의 $75 \%$ 에 도달될 경우까지 연속적으로 진행하였다.

\section{3 실험체 제작}

실험체는 $\mathrm{PC}$ 공장에서 공장제작 방식에 의하여 $\mathrm{PC}$ 부 
재를 제작한 후 조립하고, 덧침 콘크리트부분은 철근을 배근한 후 콘크리트를 현장 타설하여 제작하였다. 양생은 현장에서와 동일한 방법으로 상온에서 실시하고, 양생이 완료된 후에는 구조실험실로 운반하여 실험을 실시하는 것으로 하였다. 특히, 큰 보와 작은 보와의 접합부에서 발 생하는 불연속면은 $\mathrm{PC}$ 부재에 사용된 콘크리트강도 이상 의 무수축모르터를 사용하는 것으로 하며, 현장에서 혼합 하여 덧침 콘크리트를 타설하기 전에 현장에서와 동일한 방법으로 충전하는 것으로 하였다.

\section{4 재료시험 결과}

실험체에 사용된 철근의 인장강도시험을 실시하여 그 결과를 Table 3 에 나타내었다. 또한 실험체에 사용된 콘 크리트의 압축강도를 알아보기 위하여 공시체를 제작하 였고, 양생과정부터 실험이 실시되는 시점까지 실험체와 동일한 조건으로 양생하였다. 실험이 실시되는 시점에서 콘크리트의 압축강도를 확인하였으며, 그 결과를 Table 4 에 나타내었다.

\section{5 실험체 설치 및 실험방법}

실험은 내민보 형태로 구성하고 2점 집중하중을 가하 는 방법으로 수행하였다. 내민보 형태로 구성한 이유는 실제 상황에서 보에 작용하는 하중이 댑단부를 통하여 큰 보의 레져로 전달되기 때문에 실제 현상과 동일하게 재연 하기 위함이다. Fig. 4(a)에서와 같은 가력하중점의 결정 은 휨내력보다 전단내력에 지배되도록 하기 위함이며, 전

Table 3 Test result of bar strength

\begin{tabular}{c|c|c|c|c}
\hline Item & $\begin{array}{c}\text { Yield strength } \\
(\mathrm{MPa})\end{array}$ & $\begin{array}{c}\text { Yield strain } \\
\text { (micro strain) }\end{array}$ & $\begin{array}{c}\text { Tension strength } \\
(\mathrm{MPa})\end{array}$ & $\begin{array}{c}\text { Elastic modulus } \\
(\mathrm{MPa})\end{array}$ \\
\hline $\mathrm{D} 10$ & 570 & 2905 & 633 & $1.96 \times 10^{5}$ \\
\hline $\mathrm{D} 13$ & 492 & 2992 & 591 & $1.64 \times 10^{5}$ \\
\hline $\mathrm{D} 16$ & 482 & 2732 & 584 & $1.76 \times 10^{5}$ \\
\hline $\mathrm{D} 22$ & 485 & 2832 & 588 & $1.71 \times 10^{5}$ \\
\hline
\end{tabular}

Table 4 Test result of concrete \& grout strength

\begin{tabular}{c|c|c}
\hline Item & $\begin{array}{c}\text { Design strength } \\
(\mathrm{MPa})\end{array}$ & $\begin{array}{c}\text { Test result } \\
(\mathrm{MPa})\end{array}$ \\
\hline $\mathrm{PC}$ & 27 & 35.5 \\
\hline Cast in place concrete & 24 & 23.8 \\
\hline Grout & 27 over & 64.9 \\
\hline
\end{tabular}

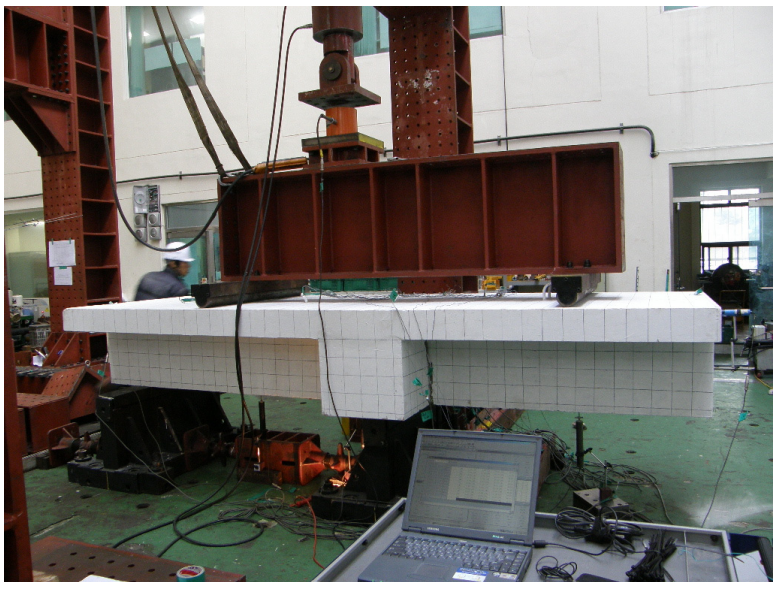

Fig. 5 State of setting specimen

단스팬비 $(\mathrm{a} / \mathrm{d})$ 가 2.0 이상이 되도록 하기 위함이었다. 실 험은 가력보의 지지점 위치에서 측정한 실험체의 변위를 기준으로 변위제어방식에 의하여 진행하며, 실험체의 파 괴시까지 수행하는 것으로 하였다. 실험체의 설치상태를 Fig. 5에 나타내었다.

\section{4. 실험결과의 분석}

실험결과의 분석은 하중-변위 곡선으로 비교하며, 하 중-변위 곡선에는 설계내력을 표시하여 설계내력에의 도 달여부도 확인하는 것으로 하였다. 레져에서 행거철근의 정착방법에 대한 구조성능 평가는 $\mathrm{BS}-\mathrm{S} 1, \mathrm{P} 1$ 및 $\mathrm{BS}-\mathrm{S} 2, \mathrm{P} 2$ 실험체의 실험결과로 분석하며, 설계하중에 따른 레져의 전단성능에 대한 평가는 $\mathrm{BS}-\mathrm{S} 1,2$ 및 $\mathrm{BS}-\mathrm{P} 1,2$ 실험체 의 실험결과로 분석하였다. 레져에 보강되는 철근의 보강 효과에 대한 평가는 $\mathrm{BS}-\mathrm{P} 0,1$ 실험체의 실험결과로 분석 하며, $\mathrm{PC}$ 작은 보를 연속성이 확보된 합성보로 설계할 경 우에 대한 전단성능의 평가 및 전단에 의한 임계단면의 위치 분석은 $\mathrm{BS}-\mathrm{P} 3,4$ 실험체의 실험결과로 분석하였다. 하중-변위 곡선 내에는 공칭전단내력도 표시하였다. $\mathrm{P}_{\mathrm{nd}}$ 는 댑단부의 공칭전단내력이고, $\mathrm{P}_{\mathrm{nl}}$ 은 레져의 공칭전단내 력이며, $\mathrm{P}_{\mathrm{nv}}$ 는 지점으로부터 $\mathrm{d}$ 만큼 떨어진 임계단면에서 의 공칭전단내력이다.

각각의 하중-변위 곡선에는 이론적인 초기강성을 나타 내고 있는데, $d=495 \mathrm{~mm}$ 는 작은 보의 유효깊이가 큰 보 의 레져부분 높이까지 포함된 상태이고 $\mathrm{d}=275 \mathrm{~mm}$ 는 작 은 보의 유효깊이가 큰 보의 레져부분이 포함되지 않은 경우를 나타내었다. 하중-변위 곡선에서 알 수 있듯이 모 
든 실험체는 작은 보의 레져부분이 큰 보와 불연속되기 때문에 작은 보의 초기 거동은 보 전체 높이가 유효깊이 가 아님을 알 수 있다.

\section{1 행거철근의 정착방법에 따른 구조성능 평가}

레져의 행거철근이 정착되는 위치에 따른 구조성능을 평가하기 위하여 Fig. 6 및 Fig. 7에 하중-변위 곡선과 최종파괴사진을 비교하여 나타내었다. Fig. 6(a)는 연속 성이 확보된 합성보 설계하중을 적용하여 레져를 설계하 였으며, 행거철근을 덧침 콘크리트에 정착한 BS-S1 실 험체와 행거철근을 $\mathrm{PC}$ 보 내에 정착한 $\mathrm{BS}-\mathrm{P} 1$ 실험체의 하중-변위 곡선 비교이다. 그림에서 알 수 있듯이 $\mathrm{BS}-\mathrm{S} 1$ 실험체가 초기에 슬립이 발생한 것을 제외하면 두 곡선의 이력거동의 상태는 동일한 상태라고 판단된다. 또한 Fig. 6(b)의 최종파괴모습에서도 최종파괴의 양상 및 균열의 위치가 동일하게 나타났다. 또한 Fig. 7(a)는 단순보 설계하중을 적용하여 레져를 설계하였으며, 행거 철근을 덧침 콘크리트에 정착한 $\mathrm{BS}-\mathrm{S} 2$ 실험체와 행거철 근을 $\mathrm{PC}$ 보 내에 정착한 $\mathrm{BS}-\mathrm{P} 2$ 실험체의 하중-변위 곡 선 비교이다. 그림에서 알 수 있듯이 BS-S2 실험체가

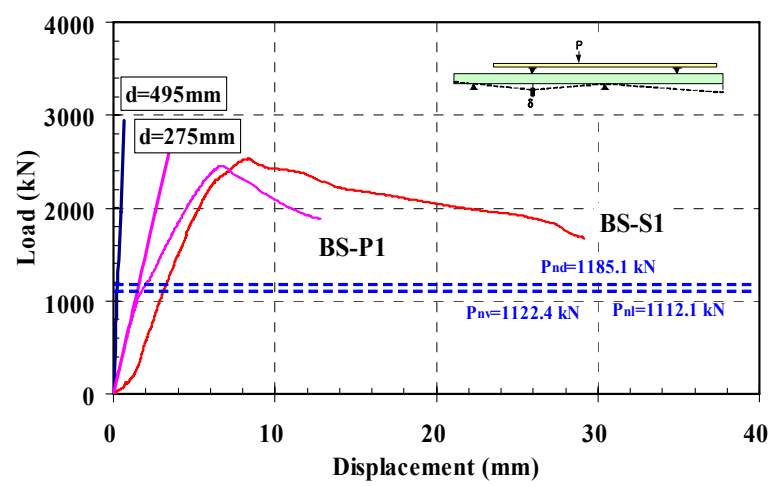

Fig. 6(a) Comparison with $\mathrm{P}-\delta$ curves according to anchored place of hanger bars in designed ledger to composite beam

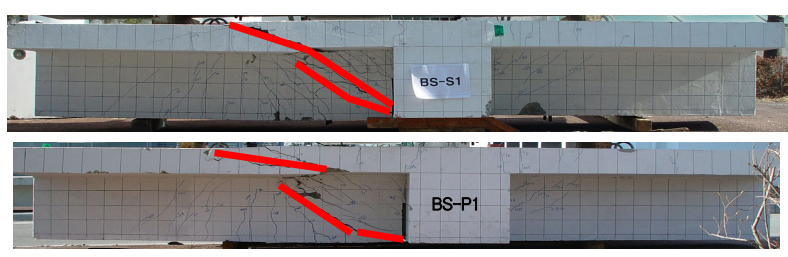

Fig. 6(b) Comparison with failures according to anchored place of hanger bars in designed ledger to composite beam
초기에 슬립이 발생한 것을 제외하면 두 곡선의 이력거동 의 상태는 동일한 상태라고 판단된다. 또한 Fig. 7 (b)의 최종파괴모습에서도 최종파괴의 양상 및 균열 위치가 동 일하게 나타났다.

따라서 레져의 행거철근이 정착되는 위치가 변화(덧침 콘크리트에서 $\mathrm{PC}$ 보 내로 위치변화)하여도 구조성능에는 영향을 미치지 않는 것으로 판단된다. 다만, 행거철근의 정착방법은 콘크리트구조설계기준에서 정의하는 전단보 강근(스터럽)의 상세 ${ }^{8)}$ 에 따라야 한다.

\section{2 설계하중에 따른 레져의 구조성능 평가}

설계하중에 따른 레져의 구조성능 평가 결과를 Fig. 8(a), Fig. 9(a)에 하중-변위 곡선으로 비교하여 나타냈 으며, Fig. 8(b), Fig. 9(b)에는 최종파괴 상태를 비교하 여 나타내었다. Fig. 8은 행거철근이 덧침 콘크리트에 정 착되어 있는 실험체이고, Fig. 9는 행거철근이 PC 보 내 에 정착되어 있는 실험체이다.

그림에서 알 수 있듯이 레져의 성능은 작은 보가 연속 성이 확보된 합성보일 때인 $\langle\mathrm{DL}+\mathrm{CL}\rangle$ 로 설계한 $\mathrm{BS}-\mathrm{S} 1$ 실험체와 작은 보가 단순보일 때인 $\langle\mathrm{DL}+\mathrm{LL}>$ 로 설계한

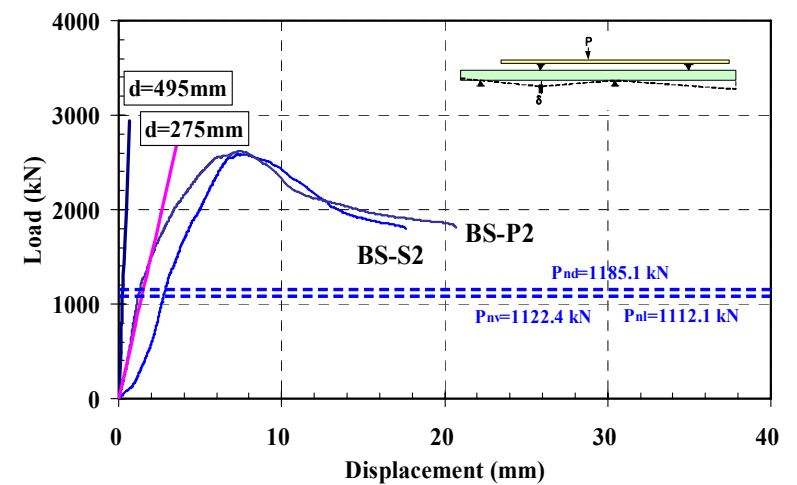

Fig. 7(a) Comparison with $\mathrm{P}-\delta$ curves according to anchored place of hanger bars in designed ledger to simple supported beam

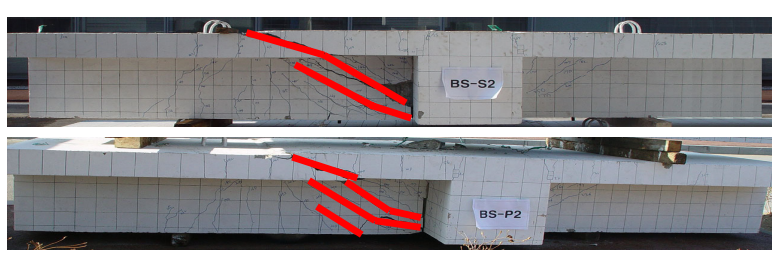

Fig. 7(b) Comparison with failures according to anchored place of hanger bars in designed ledger to simple supported beam 


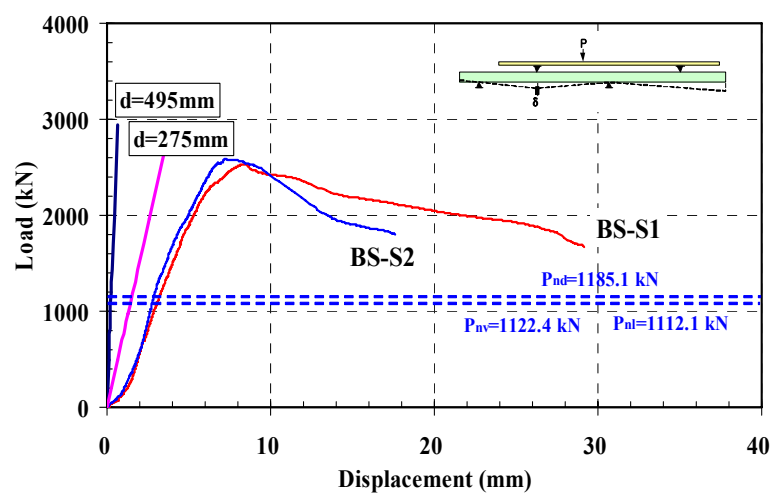

Fig. 8(a) Comparison with $\mathrm{P}-\delta$ curves according to design loads of ledger, when hanger bars anchored in slab of composite beam

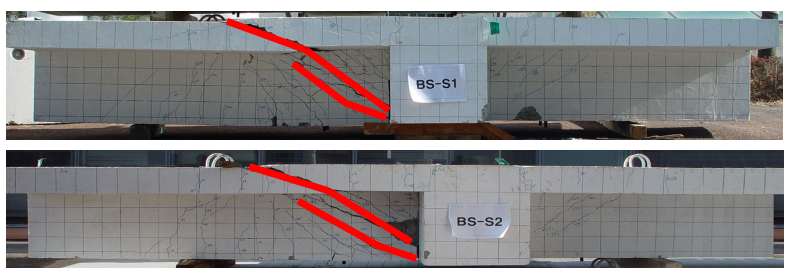

Fig. 8(b) Comparison with failures according to design loads of ledger, when hanger bars anchored in slab of composite beam

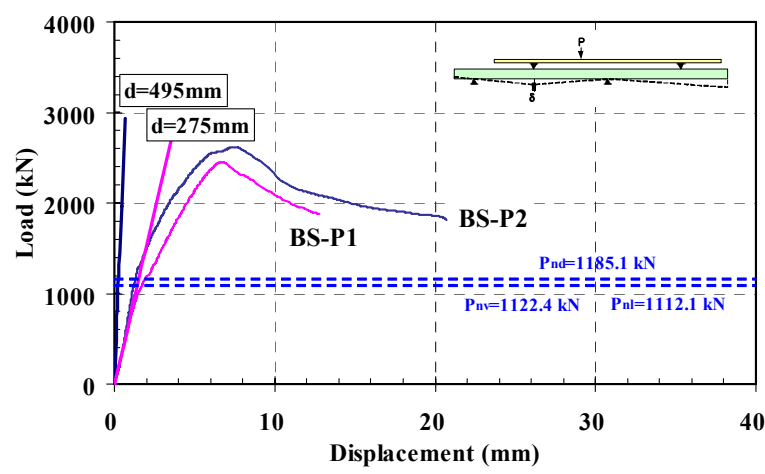

Fig. 9(a) Comparison with $\mathrm{P}-\delta$ curves according to design loads of ledger, when hanger bars anchored in PC web of composite beam

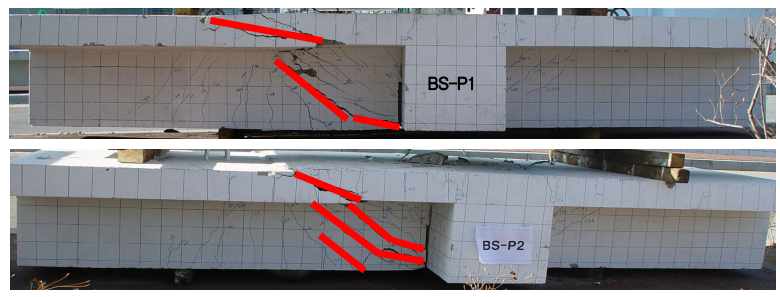

Fig. 9(b) Comparison with failures according to design loads of ledger, when hanger bars anchored in PC web of composite beamledger, when hanger bars anchored in slab of composite beam

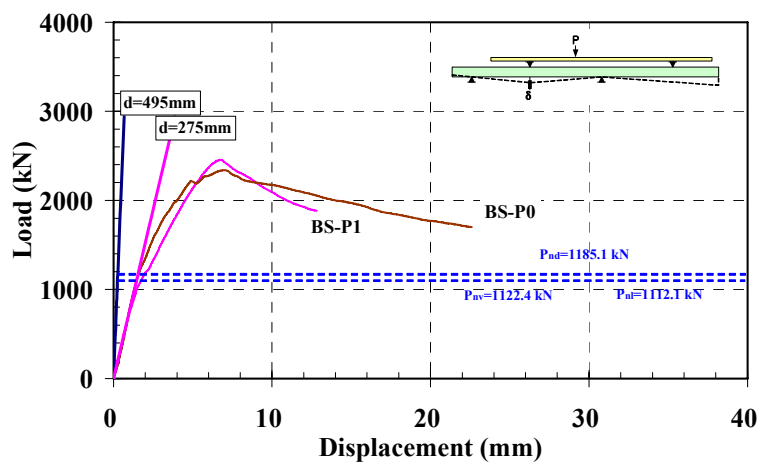

Fig. 10(a) Comparison with $\mathrm{P}-\delta$ curves according to be or not exist of ledger bars in composite beam

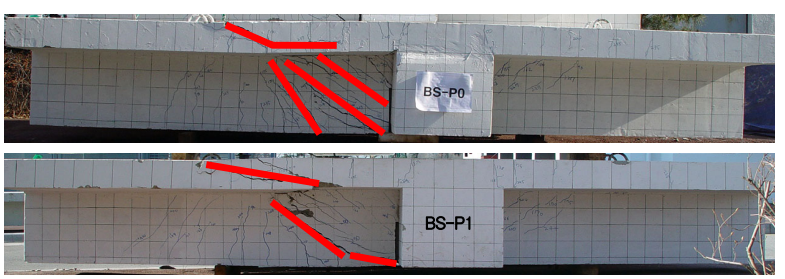

Fig. 10(b) Comparison with failures according to be or not exist of ledger bars in composite beam

$\mathrm{BS}-\mathrm{S} 2$ 실험체의 하중-변위 곡선 및 최종파괴 상태는 매우 비슷하게 나타나고 있으며, 행거철근이 PC 보 내에 정착된 $\mathrm{BS}-\mathrm{P} 1,2$ 실험체에서도 그 결과는 $\mathrm{BS}-\mathrm{S} 1,2$ 실 험체와 동일하게 나타났다.

상기에서와 같이 설계하중에 따른 레져 성능의 차이가 매우 미미하게 나타나고 있기 때문에 레져 철근의 역할을 보다 명확하게 확인하기 위하여 레져 철근의 유무를 변수 로 구조성능을 평가하였고, 그 결과를 Fig. 10에 나타내 었다. 그림에서 알 수 있듯이 레져 철근이 없는 BS-P0 실험체는 레져 철근이 있는 $\mathrm{BS}-\mathrm{P} 1$ 실험체와 거동의 특 성 및 최종파괴 상태가 동일하게 나타났다. 따라서 레져 철근의 역할은 건축물에서와 같이 활하중이 작은 경우에 는 매우 미미한 것으로 판단되며, 본 연구에서 사용되고 있는 레져는 PCI 핸드북에서와 같이 캔틸레버형 레져가 아니고 3변 지지형 레져이기 때문에 레져 철근의 역할이 미미하게 나타나고 있는 것으로 사료된다.

\section{3 전단에 의한 임계단면 위치}

보에 대한 위험단면에서의 전단설계, 댑단부의 전단설 계, 레져의 전단설계가 강도설계법에 만족되도록 설계된 실험체들의 하중-변위 곡선과 최종파괴 상태를 Fig. 11 


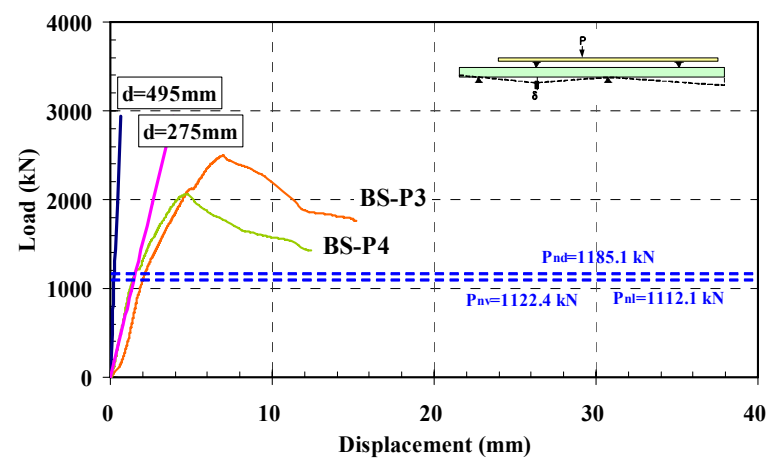

Fig. 11(a) Comparison with $\mathrm{P}-\delta$ curves according to applied loads at any critical section for shear design

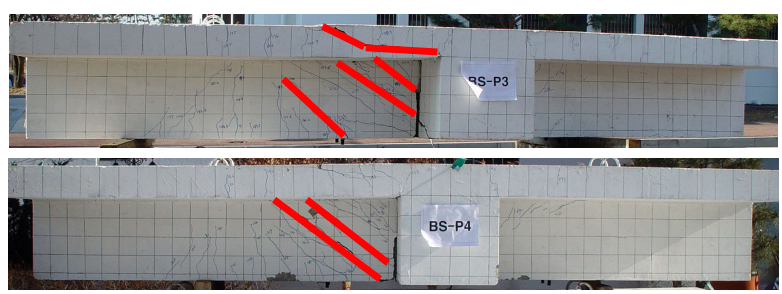

Fig. 11(b) Comparison with failures according to applied loads at any critical section for shear design

에 나타내었다. BS-P3 실험체는 연속성이 확보된 합성 보 하중 $(\mathrm{DL}+\mathrm{CL})$ 으로 댑단부와 레져가 설계되었으며, 보 에 대한 위험단면에서의 전단설계는 사용하중 $(\mathrm{DL}+\mathrm{LL})$ 으로 하였다. BS-P4 실험체는 단순보 하중 $(\mathrm{DL}+\mathrm{LL})$ 으 로 댑단부와 레져가 설계되었으며, 보에 대한 위험단면에 서의 전단설계도 사용하중 $(\mathrm{DL}+\mathrm{LL})$ 으로 하였다.

그림에서 알 수 있듯이 BS-P3 실험체가 초기에 슬립 이 발생한 부분과 BS-P4 실험체의 최대내력이 BS-P3 실험체보다 약 $25 \%$ 정도 적게 나타났지만, 공칭 설계강도 를 초과하고 있는 결과를 포함한 모든 특성이 두 실험체 모두에서 동일하다고 판단된다. 또한 최종파괴 상태에서 도 임계단면의 위치가 지지점으로부터 $\mathrm{d}$ 만큼 떨어진 위 치에서 형성된 후 댑단부로 확산되고 있음도 동일하게 나 타나고 있다.

따라서 이상의 결과는 댑단부와 레져가 덧침 콘크리트 의 타설로 인하여 완전한 합성구조가 되었기 때문에 나타 난 결과로 판단된다.

\section{4 합성보로서의 작은 보 설계 시 전단성능 평가}

4.1절부터 4.3절까지는 지지점으로부터 유효높이(d) 만 큼 떨어진 위치에서의 단면, 댑단부, 레져 등의 전단성능
에 대하여 각각 평가한 결과를 기술하였다.

평가 결과에 의하면 덧침 콘크리트의 타설에 의해 $\mathrm{PC}$ 보와 덧침 콘크리트가 합성된 보에서 댑단부 및 레져는 $\langle\mathrm{DL}+\mathrm{CL}\rangle$ 의 하중으로 설계하여도 전단성능은 확보될 수 있는 것으로 나타났으며, 임계단면은 지지점으로부터 유 효높이(d)만큼 떨어진 위치에서 형성된 후, 댑단부로 확 산되고 있음을 알 수 있었다. 그리고 레져는 PCI 핸드북 에서 설계할 때 캔틸레버 슬래브와 같은 구조일 때로 해 석하고 있는데, 본 구조물에서의 레져는 3 변고정 슬래브 와 같은 구조이므로 PCI 핸드북에서 정의하는 방법은 과 대설계의 가능성이 있는 것으로 사료된다.

따라서 $\mathrm{PC}$ 작은 보가 연속성이 확보된 합성보로 설계 될 때, 댑단부와 레져는 $\langle\mathrm{DL}+\mathrm{CL}\rangle$ 로 설계하고 지지점으 로부터 유효높이(d)만큼 떨어진 위치에서의 단면에 대한 전단설계는 사용하중으로 설계하는 것이 바람직하다고 사료된다.

\section{5. 결 론}

(1) $\mathrm{PC}$ 작은 보의 댑단부 및 $\mathrm{PC}$ 큰 보의 레져에 대한 전단성능은 $\langle\mathrm{DL}+\mathrm{CL}>$ 으로 설계하여도 작은 보의 연속성은 확보될 수 있는 것으로 나타났다. 즉 PC 작은 보의 댑단부 및 $\mathrm{PC}$ 큰 보의 레져는 시공상태 설계와 완성상태의 설계로 구분하여 설계하고 $\mathrm{PC}$ 작은 보의 단부는 연속성이 확보된 합성보로 설계 하는 것이 바람직하다고 사료된다.

(2) $\mathrm{PC}$ 작은 보의 전단 임계단면은 지지점으로부터 유 효높이(d)만큼 떨어진 위치에서 형성된 후 댑단부 로 진전되었다.

(3) 본 연구에서의 레져는 3 변고정 슬래브와 같은 구 조이므로 3 변고정 슬래브의 거동에 따른 설계를 하는 것이 바람직하다.

(4) $\mathrm{PC}$ 큰 보-PC 작은 보 접합부에서 큰 보에는 레져 의 행거철근이 배근되는데, 행거철근이 덧침 콘크 리트에 정착되지 않고 $\mathrm{PC}$ 보 내에 정착되어도 구 조적인 차이가 발생하지 않았다.

\section{참고문헌}

1. 사단법인 한국콘크리트학회, 콘크리트구조설계기준 해설, 2007, pp.523.

2. 삼성물산(주) 건설부문, 일방향 $\mathrm{PC}$ 장선 슬래브의 접합상세 
개발 및 구조성능 평가에 관한 연구, 연구보고서, 2007, pp.156.

3. 삼성물산(주) 건설부문, $\mathrm{MRS}$ 구조시스템의 접합상세 개발 및 구조성능 평가에 관한 연구, 연구보고서, 2008, pp.337.

4. PCI Industry Handbook Committee, PCI Design Handbook-Precast Prestressed Concrete, 6th Edition, Precast/Prestressed Concrete Institute, Chicago, IL, 2005, pp.736.

5. Mattock, A. H. and Theryo, T. S., Strength of Precast Prestressed Concrete Members with Dapped Ends, Research Project No. 6, Precast/Prestressed Concrete Institute, Chicago, IL, 1986, Summary Paper in PCI JOURNAL, vol. 31, No. 5, Sep.-Oct. 1986, pp.218.

6. Design and Typical Details of Connections for Precast and Prestressed Concrete, Second Edition, MNL-123-88, Precast/Prestressed Concrete Institute, Chicago, IL, 1988, pp.270.

7. Mattock, A, H. and Chan, T. C., Design and Behavior of Dapped-End Beams, PCI JOURNAL, vol. 24, No. 6, November-December 1979, pp.28-45.

8. PCA, Notes on ACI 318-08 Building Code Requirements for Structural Concrete, 2008, pp.1026.

(접수일자 : 2011년 6월 18일)

(수정일자 : 2011년 10월 11일)

(심사완료일자 : 2011년 10월 13일)

본 연구는 PC 작은 보의 댑단부와 PC 큰 보의 레져에 대한 전단성능을 평가하기 위한 전단 구조성능 실험연구이다. 일반적으 로 작은 보의 댑단부와 큰 보의 레져는 사용하중에 안전하도록 설계하고 있지만, 작은 보의 단부를 연속단으로 설계한다면 작은 보의 댑단부와 큰 보의 레져는 고정하중과 시공하중에만 안전하도록 설계할 수 있다. 이에 대한 구조성능을 평가하기 위하여 행 거철근 정착방법, 설계하중, 레져보강근유무를 변수로 총 7 개 실험체를 제작하여 전단실험을 실시하였다.

실험결과, 댑단부 및 레져가 $\langle\mathrm{DL}+\mathrm{CL}>$ 으로 설계되어도 작은 보의 연속성은 확보될 수 있는 것으로 나타났으며, 전단 임계단 면은 지지점으로부터 유효높이(d) 만큼 떨어진 위치에서 형성된 후 댑단부로 진전되었다. 그리고 PCI 핸드북에서 레져를 설계할 때 캔틸레버 슬래브와 같은 구조일 때로 해석하고 있는데, 본 공법에서의 레져는 3 변 고정 슬래브와 같은 구조이므로 PCI 핸드 북에서 정의하는 방법은 본 공법의 레져를 과대설계할 가능성이 있는 것으로 사료된다.

핵심 용어 : $\mathrm{PC}$ 큰 보-PC 작은 보 접합부, 댑단부, 레져, 전단성능 